\title{
Promoting the Catholic Cause on the Italian Peninsula: Printed Avvisi on the Dutch Revolt and the French Wars of Religion, 1562-1600
}

\author{
Nina Lamal
}

Henri of Navarre's attempt to seize Paris in 1590 was followed by interested consumers of news throughout early modern Europe; his exploits were published in various news pamphlets in the German lands, England and the Dutch Republic. ${ }^{1}$ His assault on Paris failed, because the Spanish-Habsburg army under the command of the governor-general of the Habsburg Netherlands, Alexander Farnese, came to relieve the city. This news was printed on the Italian peninsula in various cities, such as Rome, Milan, Turin and Bologna. ${ }^{2}$

Andrew Pettegree noted this Italian interest in an article on the print connections between France and the Low Countries, but the Italian peninsula did not feature strongly in his final conclusion, which focussed on the rise of news communities in northern Europe. ${ }^{3}$ In the German lands, in England, in France and in the Low Countries there existed an audience interested in reading and buying printed news on current foreign events. Pettegree also suggested that the production of news was closely aligned with the local political climate. The present chapter aims to develop and refine this argument by examining the

1 Paul J. Voss, Elizabethan News Pamphlets: Marlowe, Shakespeare, Spenser and the Birth of Journalism (Pittsburgh: University of Pennsylvania Press, 20o1); Lisa Ferraro Parmelee, Good Newes from Fraunce: French Anti-League Propaganda in Late Elizabethan England (Rochester, NY: University of Rochester Press, 1996); Andrew Pettegree, 'France and the Netherlands: the Interlocking of Two Religious Cultures in Print During the Era of the Religious Wars', in The French Book and the European Book World, ed. Andrew Pettegree (Leiden: Brill, 2007), pp. $109-28$.

2 Avviso della liberatione dell'assedio della città di Parigi. Successo del soccorso datoli. Ritirata dell'essercito di Navarra, entrata delle vettovaglie, presa di molti luoghi che l'impedivano con gran mortalità de nimici (Rome, 1590), usTC 806519; Relatione fidelissima dell'assedio di Parigi, \& sua liberatione (Turin, 1590), USTC 806597; Il vero et compito raguaglio di quanto ha valorosamente fatto il Serenissimo Duca di Parma, \& Piacenza, in liberar dall'assedio la gran città di Parigi. Insieme con la minutissima descrittione del suo viaggio (Milan, 1590), UsTC 806622; Aviso delli grandissimi disaggi, li quali ha patito la città di Parigi. Mentre è stata assediata dal re di Nauarra (Bologna, 1590), USTC 806521.

3 Pettegree, 'France and the Netherlands', pp. 126-7.

(C) NINA LAMAL, 2016 | DOI 10.1163/9789004277199_030

This is an open access chapter distributed under the terms of the Creative Commons Attribution-

Noncommercial-NoDerivatives 3.o Unported (CC-BY-NC-ND 3.0) License. 
printing of news in Italian cities. More specifically, it studies the Italian printed news on the religious and the civil wars in the Netherlands and in France, in order to discuss the function of printed news on the Italian peninsula. Will we, in the process, discern a north-south divide in Europe's production of news?

\section{Printed News}

The phenomenon of printed news on the Italian peninsula finds very little place in current scholarship on the history of news. ${ }^{4}$ Although the Italian city states were amongst the first places where news was printed at the end of the fifteenth century, scholars have scarcely studied the production of printed news sheets in the second half of the sixteenth century. ${ }^{5}$ Two reasons can be given to explain this lacuna. It tends to be assumed that the Council of Trent $\left(1545^{-63}\right)$ ended a flourishing news and print culture. ${ }^{6}$ And it is true that the authorities (be they church or state) started to monitor the world of ephemeral print more closely. This tighter control, however, does not imply the end of printed news. Secondly, there is an increasing focus within historical research on the importance of the manuscript newssheets. ${ }^{7}$ Mario Infelise has studied

4 The exception are the various studies by Sandro and Tullio Bulgarelli; for a bibliographic overview of printed news sheets in Rome during the sixteenth and seventeenth centuries see, Tullio Bulgarelli, Gli avvisi a stampa in Roma nel Cinquecento (Rome: Istituto di Studi Romani 1967); Sandro Bulgarelli, Tullio Bulgarelli, Il giornalismo a Roma nel Seicento (Rome: Bulzoni 1988). In more recent scholarship, printed information has received some attention but the avvisi a stampa have not been specifically addressed. See Ugo Rozzo, La strage ignorata. Ifogli volanti a stampa nell' Italia dei secoli XV e XVI (Udine: Forum, 2008); Filippo de Vivo, Information and Communication in Venice. Rethinking Early Modern Politics (Oxford: Oxford University Press, 2007); Rosa Salzberg, "Selling Stories and Many Other Things in and through the City": Peddling Print in Renaissance Florence and Venice', The Sixteenth Century Journal, 42 (2011), pp. 737-59.

5 Margaret Meserve, 'News from Negroponte: Politics, Popular Opinion, and Information Exchange in the First Decade of the Italian Press', Renaissance Quarterly, 59 (2006), pp. 4408o, and Kate Lowe, 'Africa in the News in Renaissance Italy: News Extracts from Portugal About Western Africa Circulating in Northern and Central Italy in the 1480 s and 149os', Italian Studies, 65 (2010), pp. 310-28.

6 Ottavia Niccoli, 'Italy', in The Oxford History of Popular Print Culture, vol. 1: Cheap Print in Britain and Ireland to 166o, ed. Joad Raymond (Oxford: Oxford University Press, 2011), pp. 193-4.

7 Brendan Dooley, The Social History of Skepticism: Experience and Doubt in Early Modern Culture (Baltimore: Johns Hopkins University Press, 1999); Renate Pieper, Die Vermittlung 
the emergence of manuscript newsletters or avvisi. $^{8}$ From the late fifteenth century onwards, due to an ever-growing demand and appetite for news, a system of handwritten newsletters developed on the Italian peninsula. In Rome and Venice, professional scribes compiled and edited handwritten newsletters, and these manuscript sheets were sent on a weekly basis to various subscribers. Infelise convincingly argued that avvisi were a crucial and dominant news medium on the Italian peninsula for the whole of the sixteenth and seventeenth centuries.

Yet, alongside manuscript avvisi, a considerable number of news reports were printed on the Italian peninsula. New data, accessible via the Universal Short Title Catalogue, reveals that between 1500 and 1600 at least 1,154 news reports were published in Italy. ${ }^{9}$ In the same period, 1,047 news items were printed in France and 1,196 in the Low Countries. ${ }^{10}$ The Italian peninsula thus had a lively news market comparable in scale and reach to France and to a lesser extent to the Low Countries (a much smaller vernacular market, and therefore comparatively well-served). The majority of the news printed in Italy was printed in Rome (288 editions) and in Venice (157 editions). ${ }^{11}$ Peter Burke has emphasised Rome's important position as the centre of the Catholic world, which played a critical role in determining the information that was collected and printed. ${ }^{12}$ Venice's position as a gateway to the Ottoman world had an impact on the news that was available in print. Alongside Rome and Venice, Milan (124 editions) and Bologna (117 editions) rank among places where news

Einer Neuen Welt: Amerika Im Nachrichtennetz Des Habsburgischen Imperiums 1493-1598 (Mainz: Philipp von Zabern, 200o); Cornel Zwierlein, Discorso und Lex Dei. Die Entstehung NeuerDenkrahmen im 16.Jahrhundertund die Wahrnehmung der FranzösischenReligionskriege in Italien und Deutschland, 1559-1598 (Göttingen: Vandenhoeck \& Ruprecht, 2006).

Mario Infelise, Prima dei Giornali: Alle origini della pubblica informazione, secoli XVI e XVII (Rome and Bari: Laterza, 2002).

9 Universal Short Title Catalogue (USTC) <http://www.ustc.ac.uk/> [28/o9/14].

10 Data from USTC using the category "news books" [28/og/14], data for England (1500-1600) 505 printed items and for Spain 369 printed items.

11 Numbers from the USTC for Rome are 282 editions and 148 for Venice, 123 in Milan and 110 in Bologna. [28/og/14].

12 Peter Burke, 'Rome as Center of Information and Communication for the Catholic World, 1550-1650', in From Rome to Eternity: Catholicism and the Arts in Italy, ca. 1550-1650, ed. Pamela M. Jones and Thomas Worcester (Leiden: Brill, 2002) pp. 253-69; Peter Burke, 'Early Modern Venice as a Center of Information and Communication', in Venice Reconsidered: The History and Civilization of an Italian City-State, 1297-1797, ed. John Martin (Baltimore: Johns Hopkins University Press, 200o) pp. 389-419. 
was frequently printed. ${ }^{13}$ At the time, Milan was the centre of Habsburg power on the Italian peninsula and Bologna was part of the Papal States.

This significant level of production of news in several cities on the Italian peninsula raises several questions. Why was news printed when a well-established system and a lively market for handwritten newsletters existed? What kind of news was printed and what was the function of printed news? Studying Italian printed news in detail offers the possibility of gaining more insight into the relationship between manuscript and printed news, and encourages a broader understanding of early modern news and information circuits.

This article studies two categories of printed news. One category consists of edicts, proclamations and peace treaties and the second category covers the commercial printed reports or avvisi a stampa. The first group has until very recently not been treated by historians as important in the history of news. ${ }^{14} \mathrm{In}$ contrast, this essay will argue that these official documents played an important role in the circulation of news on the Italian peninsula. News pamphlets are generally known as avvisi a stampa, following the frequent appearance of the word avvisi (notices) on the title pages. However, other terms such as relazione (report) and ragguaglio (report, information) were also very frequently used. ${ }^{15}$ I will refer to them as printed news reports or news pamphlets. News pamphlets dealt with a variety of subjects including festivities, processions, murders, strange births, miracles, natural events, battles and sieges. Such news reports mostly described one single event. There are, however, some rare examples of handwritten avvisi which were also printed. In Florence in 1570 the following news pamphlet was published: Copia di avvisi venuti di

13 For Milan see Massimo Petta, 'Wild Nature and "Religious" Readings of Events: Natural Disasters in Milanese Printed Reports (16th-17th Century)' in Historicizing Religion: Critical Approaches to Contemporary Concerns, ed. Bojan Borstner (Pisa: Plus-Pisa University Press, 2010) pp. 199-231; for Bologna, see Pierangelo Bellettini, Rosario Camponi, Zita Zanardi eds., Una Città in Piazza: Comunicazione e vita quotidiana a Bologna tra cinque e seicento: Biblioteca dell'Archiginnasio, Sala dello Stabat Mater, 24 Maggio-31 Agosto 2000 (Bologna: Compositori, 2000).

14 Vincent Van Zuilen, 'Les Placards de Philippe II en Flandres et Brabants', in Les écrits courts à vocation polémique, eds. Barbara Ertlé and Martin Gosman (Frankfurt am Main: Peter Lang, 2006), pp. 113-29.

15 For terminology concerning avvisi see: Johann Petitjean, 'Mots et Pratiques de l'information. Ce que aviser veut dire (XVI-XVIIe Siècles)', Mélanges de l'ecole française (2010), pp. 107-21. 
Anversa, di Spira, di Roma, di Venezia, di Spagna, di Francia, \& di Costantinopoli (A Copy of News Coming from Antwerp, Speyer, Rome, Venice, Spain, France and Constantinople).${ }^{16}$ It was a printed copy of handwritten avvisi which circulated widely on the peninsula and it included a variety of information from these different locations.

Most of these printed reports during the second half of the sixteenth century described the struggle against the Ottomans. There were surges in news production with the battle of Malta in 1565, the battle of Lepanto in 1571, and there was an almost regular supply of printed news on the long Turkish war between 1591 and ${ }^{1600 .}{ }^{17}$ The constant turmoil and the bloody confrontations between Catholics and Protestants in France and the Low Countries also attracted ample attention on the Italian peninsula. ${ }^{18}$ For many Italian contemporaries, these two wars appeared connected and during several episodes such as the siege of Paris in 1590 they clearly were. News on both conflicts was sometimes published together in the same report: in 1587 , for example, the news of the success of the siege of Sluis by Alexander Farnese was published along with news of the defeat of German troops in France. ${ }^{19}$ For an Italian Catholic audience, these events were presented as part of a single struggle against rebels and heretics.

16 Copia de diversi avisi de Roma, Napoli e Mesina, Spira, Anversa e Cipro (Venice, 1570), UstC 762012.

17 Data from USTC: 33 ephemera were published on the battle of Lepanto in 1571; see Ugo Rozzo, 'La battaglia di Lepanto nell'editoria dell'epoca e una miscellanea fontaniana', Rara Volumina, 1-2 (2000), pp. 41-69; and for the Roman avvisi see Tullio Bulgarelli, 'La battaglia di Lepanto e il giornalismo romano del Cinquecento', Accademie e biblioteche d'Italia, 29 (1961), pp. 231-9.

18 Silvia Moretti, 'La trattatistica italiana e la guerra: Il conflitto tra la Spagna e le Fiandre (1566-1609)', Annali dell'Istituto storico italo-germanico in Trento, 20 (1994), pp. 129-64; Silvia Moretti, 'Da una "allegrezza" all'altra dalla pace di Cateau-Cambrésis alla notte di San Bartolomeo. Le guerre civili in Francia nella trattatistica', Annali dellistituto storico italo-germanico in Trento, 21 (1995), pp. 229-66; Carlos H. Caracciolo, 'Protestantes y disidentes reliogosas en la relaciones de sucesos italianas (siglos XVIXVII)', in Representaciones de la alteridad, ideológica, religiosa, humana y espacial en las relaciones de sucesos, publicadas en España, Italia y Francia en los siglos XVI-XVIII, ed. Patrick Bégrand (Paris: Presses Universitaires de Franche-Comté, 2009), pp. 173-85.

19 La terza rotta delli hiretici (sic) in Francia con la presa dell'Escluse del Serenissimo Signor Duca di Parma, \& con altri particolari, come leggendo intenderete (Macerata, 1587), USTC 80627; Copia di una lettera venuta da Torino. Nella quale sinarra la presa di Anclusa fortezza di grandissima importanza, città posta in mare ottenuta dal Serenis. Duca di Parma in Fiandra (Rimini, 1587), ustC 806194. 


\section{Official Documents}

The news-bearing potential of official proclamations and edicts has only recently begun to be recognised by historians. Sara Barker has rightly suggested that "the act of translation turned the official publication of the original culture into the news source of a translated culture". ${ }^{20}$ Official documents are a particular and important part of the transmission of foreign news. We see this when we investigate which foreign official documents ended up on Italian printing presses.

The edict of the Parliament of Paris against the Huguenots on the 28 of July 1562 was printed both in Milan and in Padua in the same year. ${ }^{21}$ Several other royal edicts, in which the French kings granted rights to the Huguenots, were also published. The edict of Amboise (1563) and the edict of Beaulieu (1576) were published both in Venice and in Milan. ${ }^{22}$ The Venetian printer of the edict of Amboise added on the title page that it was translated faithfully from French into Italian. Publishers were conscious of the importance of a good translation to make the news trustworthy. The Milanese printer, Pietro Tini, announced proudly he was the first to publish the terms of Antwerp's surrender to Alexander Farnese in 1585 translated from French into Italian "to add splendour to the clearest light". ${ }^{23}$ This suggests that it was important to be the first to publish these treatises, which were considered to be the latest news. The reference to the clearest light, and thus to Alexander's victory, further highlights that these kinds of official publications were printed because they were thought to be good news. While it might have been difficult for readers to understand fully the formal language of such official documents, their main

20 Sara Barker, "'Newes Lately Come": European News Book in English Translation', in Renaissance Cultural Crossroads: Translation, Print and Culture in Britain, 1473-1640, ed. Sara Barker and Brenda M. Hosington (Leiden: Brill, 2013), pp. 227-44, at 230.

21 Decreti della corte del parlamento di Parigi Dì 28 \& 30 di luglio prossimo passato, contra li ribelli e seditiosi, quali in modo \& forma hostili han preso l'armi contra'l re nel regno suo. Et spogliate, e saccheggiate le chiese, \& case de catholici, come legendo intenderete (Milan, 1562), ustc 830789; I Decreti della corte del parlamento di Parigi di vinti otto e trenta di luglio prossimo passato contra li ribelli e seditiosi, quali in modo \& forma hostili han preso l'armi contra'l re nel regno suo (Padua, 1562), UsTc 830790.

22 L'Editto et capitoli del re Carlo IX (Venice, 1563), UstC 830792 or Editto del re di Francia, sopra la pacificazione de tumulti del suo regno (Milan, 1576), USTC 830779.

23 Copia delli articoli overo capitoli stabiliti, \& conclusi per la resa della città d'Anversa, mandate dal Sereniss. Principe di Parma all'Eccellentiss. Sign. Duca di Terranova \&c. Governatore del Stato di Milano, \& capitano general di Sua Maestà in Italia. Tradotta de Francese in Lingua Italiana (Milan, 1585), UstC 805984, sig. A2. 
message was always clear. These publications announced the end of a conflict or at least a way of appeasing that conflict. In 1574, for example, the general pardon granted to the people of the Low Countries by Philip II was published in Bologna, Venice and Milan. ${ }^{24}$ The peace treaty of Vervins (1598), which ended the conflicts between France and Spain, was published in more than ten Italian cities. $^{25}$

24 Il perdono generale che il re Filippo concede a tutti paesi, stati, et luochi di Fiandra che voranno ritornare alla solita, \& antica obedienza. Con il numero de personaggi che sono esclusi dal sudetto perdono fuori. Et con la restitutione de beni, honori, \& gradi, a coloro che lo accettaranno. Publicato dal signor comendator maggiore capitano generale, \& luogotenente per detta m. in quelle parti di Fiandra (Milan, 1574) copy in Archivio di Stato di Firenze (ASF), Mediceo del Principato (MdP), 4254, fos. 484-7; Il perdono generale che il re Filippo concede a tutti paesi, stati, et luochi di Fiandra che voranno ritornare alla solita, \& antica obedienza (Bologna, 1574), USTC 828980 and Il perdono generale che il re Filippo concede a tutti paesi, stati, et luochi di Fiandra che voranno ritornare alla solita, \& antica obedienza (Venice, 1574), ustc 828981 .

25 Capitoli della pace convenuti, et stabiliti tra le due maestà, christianissima, e catholica. Con l'inclusione anco del serenissimo di Savoia. Publicati in Brusseles alli $x x$ aprile 1598. Et poi in Lione, et Turino (Piacenza, 1598), usTC 830825; Capitoli della pace convenuti et stabiliti tra le due maestà, christianissima e catholica, con l'inclusione anco del serenissimo Savoia. PubIicati in Brusseles, alli XX aprile 1598 et poi in Lione, et Turrino (Bologna, 1598), USTC 830817; Capitoli et conditioni della perpetua pace, \& confederatione stabilita fra gli altissimi, \& potentisimi prencipi Henrico quarto per la Dio gratia re di Francia, e di Navarra, christianissimo, \& Philippo II per Dio gratia re delle Spagne, cattolico. Tradotte fedelmente in italiano dall'original francese stampato in Parigi, dal sig. Camillo Bergameno da Trento (Ferrara, 1598), USTC 830820; Capitoli et conditioni della perpetua pace, \& confederatione stabilita fra gli altissimi \& potentissimi principi Philippo II re delle Spagne \& Henrico IIII re di Francia tradotti fidelmente in italiano dall'originale francese stampato in Parigi (Palermo, 1598), USTC 857160; Capitoli et conditioni della pace et perpetua amicitia fatta fra Henrico IIII re christianissimo di Franza et Filippo re cattolico di Spagna l'anno 1598 (Brescia, 1598), UsTC 830815; Capitoli et conditioni della perpetua pace, \& confederatione stabilita fra gli altissimi, et potentissimi prencipi Henrico IIII per la Dio gratia re di Francia, e di Navarra, christianissimo, et Filippo II per Dio gratia (altresi) re delle Spagne cattolico (Vicenza, 1598), USTC 830816; Capitoli et conditioni della perpetua pace, \& confederatione stabilita fra gli altissimi, \& potentisimi prencipi Henrico quarto per la Dio gratia re di Francia, e di Navarra, christianissimo, \& Philippo II per Dio gratia (altresi) re delle Spagne, cattolico. Tradotte fedelmente in italiano dall'original francese stampato in Parigi, dal sig. Camillo Bergameno da Trento (Modena, 1598), USTC 830818; Capitoli et conditioni della perpetua pace, \& confederatione stabilita fra gli altissimi, et potentissimi prencipi Henrico IIII per la Dio gratia re di Francia, e di Navarra, christianissimo, et Filippo II per Dio gratia re delle Spagne cattolico (Turin, 1598), USTC 830822; Capitoli et conditioni della perpetua pace, \& confederatione stabilita fra gli altissimi, et potentissimi prencipi Henrico IIII per la Dio gratia re di Francia, e di Navarra, christianissimo, et Filippo II per Dio gratia re delle Spagne cattolico (Rome, 1598), USTC 
The translators of these official documents mostly remain unknown, with only a very a few exceptions. Henri III's speech at Blois in 1588 was published in Padua and translated into Italian by Jean Peschant, professor of theology at the Sorbonne in Paris. ${ }^{26}$ In some cases it was the publisher himself who was responsible for the translations. Giorgio Marescotti, publisher in Florence, sometimes translated from French into "Tuscan". ${ }^{27} \mathrm{He}$ was born in France but started a successful printing firm in Florence. Marescotti stated that he printed the speech of the Cardinal of Bourbon in Peronne in 1585 "to give satisfaction to many individuals, who want to know about the causes of the new turmoil in the kingdom of France". ${ }^{28}$ Numerous other speeches and edicts during the 1580 and 1590 s were published. ${ }^{29}$ Many of these documents were published in one collection by Comino Ventura in Bergamo in 1593 under the title Raccolta d'alcune scritture pubblicate in Francia de imoti di quel regno (Collection of Some

830823; Capitoli et conditioni della perpetua pace, \& confederatione stabilita fra gli altissimi, et potentissimi prencipi Henrico IIII per la Dio gratia re di Francia, e di Navarra, christianissimo, et Filippo II per Dio gratia re delle Spagne cattolico (Orvieto, 1598), USTC 830824; Capitoli, et conditioni della pace. Fatta fra Filippo re catholico di Spagna \&cc. et Henrico IIII. re christianissimo di Franza, \&c. L'anno 1598. aggiunti gli capitoli della pace trattata nel Castello in Cambresi; l'anno 1559 (Milan, 1598), ustc 857159; I capitoli, et le conditioni della pace, \& perpetua concordia trattata fra gli altissimi, e potentissimi prencipi, Filippo re catolico di Spagna, \& Henrico quarto di questo nome re christianissimo di Francia, l'anno 1598. Aggiuntovi ancora le conditioni della pace trattata al Castello in Cambresi l'anno 1559. frà il detto re catolico di Spagna, \& del già Henrico secondo christianissimo re di Francia (Mantua, 1598), ustc 857161.

26 Ragionamento di Henrico III re di Francia etc. Fatto nel principio de' Tre Stati Generali del suo regno, nella città di Bles, a 16 di ottobre 1588. Tradotto dal francese nell' italiano dal sig. Giovanni Piscante dottore della santa theologia, della Sorbona di Parigi (Padua, 1589), USTC 835622 .

27 Dichiaratione della volonta del Re sopra li nuovi tumulti di questo regno. Tradotta di lingua franzese in Toscana da Giorgio Marescotti. (Florence, 1585), ASF, MdP, 4878 (not foliated); Dichiarazioni delle cause, che hanno mosso monsignor il cardinale di Borbone ... di opporsi a quelli che vogliono souvertire la religione, e lo stato (Florence, 1585), ustc 816620. For more information on Marescotti, see Franco Pignatti, 'Marescotti', in Dizionario Biografico degli Italiani (DBI) 70 (2007).

28 Dichiarazioni delle cause, che hanno mosso monsignor il cardinale di Borbone, sig. A2.

29 Articoli a nome del re di Francia et regina sua madre, per una parte monsignor il cardinale di Borbone, et monsignor de Guisa per l'altra parte, statti ultimamente approntati. Con un editto del re di Franza per confirmatione de detti articoli circa il fatto della religion catholica (Milan, 1588) USTC 761893; La curiosa, et grave aringa fatta nel consiglio generale de i tre stati di Francia il 2 d'aprile 1593 (Bologna, 1593), ustc 806803; Dichiaratione dei signori prencipi pari, ufficiali della Corona, et deputati ne gli Stati Generali della Francia (Rome, 1593), USTC 830810. 
Writings Published in France on the Uprisings in that Kingdom). ${ }^{30}$ In the preface to the reader Ventura wrote that he had published these documents because "from these writings it was possible to discover the true causes of the discords in the kingdom of France, and to please many, who eagerly desired them". ${ }^{31}$ It is clear that Ventura knew how to advertise his publications but his explanation might also help us to understand why many of these documents were published together: these edicts and speeches offered an insight into the motivations and the underlying reasons for the past conflict in France.

\section{Printed Letters}

Most of the printed news in the early modern period deals with military affairs. Battlefield reports were a fairly standardised genre, describing the troop movements, the tactics, the actual battle and giving figures of how many soldiers of both camps were killed or taken hostage. The majority of news reports were based on private correspondence. The titles frequently referred to letters: a letter written by a Florentine merchant to a friend in Italy related the news on the progress of the French king's campaign against the Huguenots in $1562 .{ }^{32}$ David Randall has argued in his work on English military printed news that letters were favoured because they provide a standard of credibility to the reader. ${ }^{33} \mathrm{~A}$ printed copy of a letter by Curtio Lirelli on the military situation in France in 1562 illustrates this. ${ }^{34}$ The publisher, Pasquato, reproduced this letter verbatim and kept every element in the printed version that could give proof of its authenticity. By publishing these letters, printers reached a broader audience than the restricted circle of influential citizens to whom the letters had been originally addressed.

30 On this collection see Pier Maria Soglian, Un editore di confine e I troubles de France [2005] <http://www.bibliotecamai.org/editoria/edizioni/comino_ventura.htm> [3 May 2015].

31 Raccolta d'alcune scritture publicate in Francia nel principio degli ultimi moti di quel regno (Bergamo, 1593), UstC 806832, sig. A2.

32 Lettera che contiene minutamente gli avisi de i progres, delle prattiche, che sono andate attorno fra la M. del re Christianis. \& il Principe di Condè ... Scritta da un mercante fiorentino da Parigi ad un Gentilhuomo amico suo in Italia (Ferrara, 1562), Ustc 804217.

33 David Randall, Credibility in Elizabethan and Early Stuart Military News (London: Pickering \& Chatto, 2008).

34 Curtio Lirelli, Tutte le battaglie passate nella Francia tra catholici et ugonotti fino a questa hora presente. Con la presa della città di Macone, Tournus, Burges, Villabella, \& altre de' principali della Francia, che si erano ribellate alla fede catholica, \& a sua maestà christianissima (Padua, 1562), ustc 838246; Curtio Lirelli, Tutte le battaglie passate nella Francia tra catholici et ugonotti fino a questa hora presente (Bologna, 1562), USTC 838247. 
In addition to private correspondence, publishers made use of anonymous manuscript avvisi. An avviso on the battle of Jarnac was written from Metz on 21 March $1569 .{ }^{35}$ This entire handwritten avviso was printed in Venice by Domenico Farri, but he replaced the date and place of the original avviso with a heading which referred to the actual date of the battle of Jarnac (13 March 1569). ${ }^{36}$ Publishers thus started to make small adaptations to assist their readers. Another pamphlet printed in Venice on the battle of Jarnac promised its reader: 'to narrate also other new and marvellous things'. ${ }^{37}$ The title-pages offered publishers the necessary means to publicise the events. In a news pamphlet on the decisive battle of Dreux in 1562, during which the Prince of Condé was taken prisoner, it was advertised that it contained "delightful things for the historians and useful things for the teachers of wars". ${ }^{38}$ Some of the titles had adjectives such as "true" or "certain" which emphasised the veracity of the events described within the report. News pamphlets claimed to provide their readers with the latest and the most reliable information on a specific battle or siege. New pamphlets first and foremost served to celebrate Catholic victories against the Protestant enemies, who are consistently labelled as "heretics" and "rebels". Only decisive Catholic victories were celebrated in print, such as the battle of Dreux (1562), Jarnac and Moncontour (1569) in France, the battle of Mook (1574) and the sieges of Maastricht (1579) and Antwerp (1585) in the Low Countries. Some of these events, for instance the battle of Moncontour, were accompanied by other printed material such as illustrated news prints depicting the battle. ${ }^{39}$

Italian publishers did not publicise Catholic defeats; to this extent they presented their reading public with a distorted picture of reality. For this reason in order to be able to follow the on going events in France and the Netherlands in

35 ASF, MdP 1080, fos. 284-5.

36 Lettera scritta dalla corte del re christianissimo, nella quale si racconta il successo della giornata seguita a'XIII di marzo, tra i catolici, et gli ugonotti (Venice, 1569), USTC 804669.

37 La morte del Principe di Condè, con gli avisi della vittoria, che ha havuto il Fratello del Re Christianissimo contra gli Ugonotti adesso di novo. Ove s'intende di molti gran personaggi, che sono stati presi, \& ammazzati, fra i quali di Mons. Di Mongomeri, che già amazzò Re Henrico. Con particolari di grandissima importanza. Et altri avisi dalla cote del Re Catholico, della Rebellione del Regno di Granata, ilqual si è sollevato nuovamente. Appresso si narra altre cose maravigliose, \& nove (Venice, 1569), ustc 804680.

38 Avisi nouamente venuti de le cose di Francia. Dove sintende minutamente il principio, \& il fine della giornata fatta tra Chiatres, \& Ondan con il numero delle genti d'arme, e cavalli de l'uno \& l'altro essercito, \& anco li strattagemi usati dal Duca di Ghisa, \& del Principe di Conde (Padua, 1563), ustc 804251.

39 For example: Vitoria di Catolici contra hugonotti (1569); for more information on news prints see, Philip Benedict, Graphic History: The Wars, Massacres and Troubles of Tortorel and Perrissin (Geneva: Droz, 2007). 
all their complexity, Italian readers had to supplement their purchasing of pamphlets with the weekly manuscript avvisi. News of a battle was only printed when it was certain the Catholics had defeated the Protestants. From the stream of news in manuscript avvisi printers singled out which battles were important and memorable victories. The two media differed in other respects. Manuscript avvisi mostly presented the news in short paragraphs and in dispassionate and factual ways. News pamphlets provided a narrative and an interpretative framework to the readers. For instance, according to a pamphlet on the battle of Mook (1574) in the Low Countries, God had intervened to grant the Habsburg army this victory in order to re-establish his church and to confuse his enemies. ${ }^{40}$ In an address to the reader the publisher of avisinovamente venuti de le cose di Francia (Notices Newly Arrived on the Events in France) compared the battle of Dreux (1562) to the famous battle of Ravenna in 1512 as it had been described by Francesco Guicciardini, where, despite the death of their commander Gaston de Foix, the French troops defeated the Habsburg army. ${ }^{41}$ This comparison thus contextualised the battle of Dreux to an Italian audience by referring to their own recent past.

This attempt to make clear the relevance of events abroad to an Italian readership was not uncommon. A news pamphlet on the sieges of Poitiers and Châtterault in 1569 described the attacks by the Italian troops but gave particular attention to the Tuscan soldiers. ${ }^{42}$ This news was printed in Florence and provided the Florentines with an account of the military valour of their own soldiers who had recently been sent to France by the Grand Duke of Tuscany. In that same year a poem in ottava rima, celebrating a victory of "our Italians", was published in Viterbo and Florence. ${ }^{43}$ The poem narrated a story of ten Italian soldiers who killed ten Huguenots in a skirmish which allegedly had taken place on 5 September 1569 . The Italians, were presented as true Christians and honourable knights. This poem is a late example of contemporary events being

40 Vera relatione della rotta che e stata data in Fiandra al conte Lodovico di Nasao con molti altri signori che lo seguivano nel giorno 14 d'aprile 1574 (Bologna, 1574), sig. A6.

41 Auisi nouamente venuti de le cose di Francia (Padua, 1563), ustc 804251, sig. A1.

42 Ultimi avisi di Francia et di molti luoghi, per li quali s'intende l'assedio di Pontieri posto dalli Ugonotti \& l'assalto dato da nostri Christiani à Scialterion. Et il soccorso dato dalli Italiani in quest'impresa \& particolarmente da soldati Thoscani (Florence, n.d.), only copy in Biblioteca Nazionale di Firenze.

Abbatimento fatto di nuovo in Francia fra dieci cavalieri christiani, \& dieci heretici, i quali hanno combattuto d'accordo in Steccata di Tolosa, per le differenze che s'intendono. Col nome delli Padrini, che gli condussero in campo chiuso, \& d'alcuni Italiani, che hanno havuto l'honore di questo duello, cosa degna d'esser intesa (Florence, 1569). It was first published in Viterbo according to the title page, but I have not been able to locate a copy. 
adapted to ottava rima, inspired by Ludovico Ariosto's Orlando Furioso; such poems were often sung out loud by pedlars in the cities. ${ }^{44}$ In one of the newssheets on Moncontour, the military valour of the Italian troops in the battle was also stressed repeatedly. ${ }^{45}$ Instead of singling out the acts of Tuscan soldiers, this news pamphlet portrayed the battle of Moncontour as an Italian victory. The banners conquered by the Count of Santa Fiore's Italian troops during the battle of Moncontour were sent to Rome and put on display in the Basilica of St. John Lateran. ${ }^{46}$ The celebration of Italian military heroes was also prominent in news pamphlets on the successful siege of Antwerp in 1585 by Alexander Farnese. ${ }^{47}$ These news accounts were meant to glorify the Italian nation. ${ }^{48}$ The Italians were valorous Christian soldiers who defended the Catholic Church.

\section{Polemical News}

News on military victories was not the only news to be printed in Italy. Some of the murders and massacres in France and the Low Countries received ample

44 Rosa Salzberg, 'In the Mouths of Charlatans: Street Performers and Pamphlets in Renaissance Italy', Renaissance Studies, 24 (2010), pp. 638-53.

45 Gli ultimi, et veri avisi secondo le lettere venute dal campo dal signor conte Santa Fiora, \& d'altri signori italiani della felicissima vittoria contra gli Ugonotti in Francia, dove si narrano per ordine tutt'i successi, e il numero de morti, \& feriti dell'una \& l'altra parte. Con un sonetto al re christianissimo (Viterbo, 1569), ustc 804698.

46 For the manuscript avvisi see ASF, MdP 308o, fos. 626, 634, 641v.

47 Lorenzo Pontirolo, Nuovo aviso, e particolar discorso, della mirabile espugnatione d'Anversa con le capitulationi, \& trattati di essa. Ottenuta, dal serenissimo invittissimo \& massimo Alessandro Farnese. Con le solennità, e trionfi fatti mentre s.A. Sereniss. prese l'ordine del Tosone, di S.M. Catholica (Milan, 1585), ustC 806036. This report was reprinted in several cities: Lorenzo Pontirolo, Nuovo aviso, e particolar discorso, della mirabile espugnatione d'Anversa con le capitulationi, \& trattati di essa. Ottenuta, dal serenissimo invittissimo \& massimo Alessandro Farnese. Con le solennità, e trionfi fatti mentre S.A. Sereniss. prese l'ordine del Tosone, di s.M. Catholica (Brescia, 1585), ustc 806038; Lorenzo Pontirolo, Nuovo aviso, e particolar discorso, della mirabile espugnatione d'Anversa con le capitulationi, \& trattati di essa. Ottenuta, dal serenissimo invittissimo \& massimo Alessandro Farnese. Con le solennità, e trionfifatti mentre s. A. Sereniss. prese l'ordine del Tosone, di s. M. Catholica (Bologna, 1585), ustc 806037; Lorenzo Pontirolo, Nuovo aviso, e particolar discorso, della mirabile espugnatione d'Anversa con le capitulationi, \& trattati di essa. Ottenuta, dal serenissimo invittissimo \& massimo Alessandro Farnese. Con le solennità, e trionfi fatti mentre S.A. Sereniss. prese l'ordine del Tosone, di s.M. Catholica (Verona, 1585), USTC 806039 .

48 On national identity in early modern Italy see Marco Sciarrini, 'La Italia Natione'. Il sentimento nazionale italiano in età moderna (Milan, 2004). 
attention in news pamphlets. The St Bartholomew's Day massacre on 24 August 1572 was one of the seminal events in the French wars of religion and immediately recognised as an event of European significance. ${ }^{49}$ On 22 August Gaspard de Coligny, leader of the Huguenots, was shot and severely wounded. This attack only further heightened the tensions between Catholics and Huguenots in Paris; within days, following the killing of Coligny on the king's command, the Catholic population started to murder the Huguenots. In Rome, this news was well-received by the pope: it was hoped that this meant the complete destruction of the Huguenot movement. ${ }^{50}$ Celebrations were held in Rome and in Venice to give thanks. Several news pamphlets recounting these events were published in both cities. ${ }^{51}$ In Intiera Relatione della morte dell'ammiraglio (Entire Report on the Death of the Admiral) written by an Italian residing in Lyon, the massacre was presented as a "true judgment by God".52 Moreover, according to this anonymous writer, Charles Ix had finally become the true Most Christian King because he had shown leadership. Another account entitled Summario di tutto la note Francesca (Summary of all events during the French night) also rejoiced that the Huguenots, this "plague" and "sect" had been eradicated. This pamphlet is particularly interesting because an anonymous author summarised the events using different reports "for the Brescian". ${ }^{3}$ It was clearly addressed to a Brescian audience and there were

49 See Andrew Pettegree, The Invention of News. How the World Came to Know about Itself (London: Yale University Press 2014), pp. 145-51.

5o Ordine della Solennissima Processione fatta dal Sommo Pontifice nell'alma citta di Roma per la felicissima nova della destruttione della setta ugnotana. Con la inserittione posta sopra la porta della chiesa S. Luigi in un panno di setta pavonazza a lettere d'oro maiuscole (Rome, 1572).

51 Il vero successo occorso nella citta di Parigi contra l'armiraglio, e suoi seguaci ugonotti (Venice, 1572), USTC 80506o; Ultimo et vero raguaglio di tutto il successo avvenuto in Parigi contra l'armiraglio, et suoi seguaci Ugonotti, dove si ha particulare et vero avviso della morte di detto armiraglio et suoi seguaci, con la tottale ruina di tutti li Ugonotti, con'molti altri particolari ultimamente venuti, come leggendo vedrete (Rome, 1572), Ustc 805061. See also T. Bulgarelli, 'Roma e la notte di S. Bartolomeo negli avvisi a stampa dell'epoca', in Accademie e Biblioteche d'Italia XXXII (1964), pp. 339-45.

$5^{2}$ Intiera relatione della morte dell'ammiraglio, \& altri capi suoi complici. Con la mortalita degli ugonotti, per ordine di sua Maesta Christianissima fatta in Parigi, Lione, \& altri luoghi del Regno di Francia (Rome, 1572), ustc 805013. At the end of the report: 'Di Lione il di ultimo di agosto 1572'.

53 Summario di tutto il successo della notte Francesca, Occorso nel Regno di Franza intorno la grande occisione fatta per sua Maestà Christianissima, ove si vede l'ordine del tradimento, \& dell'occisione, con il numero de gli ugonotti occisi, \& il nome di principali capi ugonotti morti in quella tremenda notte. Estratto da diversi riporti per il Bresciano (Brescia, 1572), USTC 805053 . 
references to fellow Brescians residing in Lyon who had written letters describing the massacres in both Paris and Lyon. The anonymous author described how members of the Italian nations in Lyon had taken part in the killing of the Huguenots in that city, following the orders of the king and the city council. All the reports concluded with the story that a tree had started to blossom after the massacre. This was interpreted by Catholics as a clear sign that heresy had been rooted out.

Other news pamphlets in this category also had a very clear polemical undertone. In July 1584 William of Orange, the leader of the revolt against Philip II, was shot dead in Delft by Balthasar Gérard. Reports of Gérard's execution were published in Rome, Bologna, Milan, Palermo and Carmagnola. ${ }^{54}$ This account was probably based on a handwritten Latin report that originated in Catholic circles in the Low Countries. It was also translated into Dutch, French, German and published in Douai, Cologne and Paris. ${ }^{55}$ The report did not describe the death of Orange in great detail but it gave a detailed description of the torture and subsequent execution of his murderer. Gérard was presented as a Catholic martyr who had died for a higher purpose by killing a tyrant and an enemy of the Catholic faith.

A similar narrative can be observed with the news of the murder of the king of France, Henri III, in 1589. The Vera Relatione dell'Estrana, et improviso morte d'Henrico di Valoys (True Report of the Strange and Sudden Death of Henri of Valois) justified the murder of Henri III by the Dominican friar Jacques Clément as an act of God. According to the pamphlet, one night an angel had appeared to Clément who had shown him a sword and had told him to deliver France of its tyrant. Following this vision, he went to see a religious friend who convinced him it would be a saintly and laudable act to kill the French king. Clément then decided to give his life for this higher purpose. Just like Gerard,

54 Avviso dell'aspra et crudel morte data a Baldassare Borgogne in Delfi d'Hollandia \& la sua constantia. Per haver ammazato il Principe de Orange inimico della Santa Fede Cattolica (Rome, 1584), USTC 805865; Adviso dell'aspra et crudelimorte data a Baldassare Borgognese in Delfi (Palermo, 1584), ustc 805856; Aviso dell'aspra et crudel morte datta a Baldassarre Borgognone in Delfi d'Hollandia (Milan, 1584), ustc 805866; Avviso dell'aspra et crudel morte (Carmagnola, 1584), ustc 805867.

55 Les cruels et horribles tormens de Balthazar Gerard vrai martyr souffertz en l'execution de sa glorieuse \& memorable mort. Pour avoir tué Guillaume de Nãssau Prince d'Orenge ennemy de son Roy \& de l'Eglise Catholique. Mis en françois d'un discours latin envoyé de la ville Delft au Comté de Hollande (Paris, 1584), USTC 4145; Le glorieux et triomphante martyre de Balthazar Girard advenu en la ville de Delft (Douai, 1584), USTC 30819; Warhafftige und eigentliche Beschreibung, von der Geburt, Leben und Sterben dess Printzen von Orangien, Graff Wilhelm vonn Nassauw, umbkommen ist (Cologne, 1584), USTC 705560. 
Clément was presented as a Catholic martyr. According to the title page of this anonymously printed Italian news pamphlet, it was translated from a French original printed in Lyon. ${ }^{56}$ The printer of this French original was Jean Pillehotte, who also had published an Italian translation in Lyon. Several printers in Turin, Ferrara and other cities in Italy re-issued Pilehotte's Italian edition. Pillehotte was amongst the most prolific of the Lyonese League printers. ${ }^{57}$ He had important contacts with members of the League such as the Duke of Mayenne, the Bishop of Lyon and the Jesuits. This pamphlet on Henri's death is one of the many polemic League news pamphlets which were translated and reprinted on the Italian peninsula.

During the first wars of religion printed reports referred to copies of letters despatched from Lyon, but after 1585 , with the rise of the Catholic League, most Italian news pamphlets were translations of French editions which had been printed in Lyon. The city was an important commercial and financial centre in sixteenth century Europe. It was of vital importance for the trade between the Italian peninsula and France and was home to a large community of Italian merchants and bankers from Milan, Lucca, Florence and Genoa. ${ }^{58}$ Scholars have already stressed the importance of these strong links between Lyon and several other Italian cities, such as Turin, Bergamo, Milan, Brescia and Venice, for the circulation of books and commercial goods. ${ }^{59}$ These networks also proved very important for the circulation of news on the French wars of religion. When the Catholic League took hold of the Parisian and Lyonese printing presses, this strongly influenced the nature and tenor of printed news on the Italian peninsula. ${ }^{60}$

$56 \quad$ Vera Relatione dell'Estrana, et improviso morte d'Henrico di Valoys. Per permissione di Dio avvenuta in $S$. Cloù all'hora che haveva messo l'assedio alla città di Parigi il martedì primo d'agosto 1589. Per le mani d'un Frate dell'ordine de i Giacopini Estratta dal proprio Originale di Lione, \& tradotta dalla lingua Francese nella nostra Italiana (n. p., n. d.), USTC 763949; and Vera relatione dell'estranea, \& improvisa morte di Henrico re di Francia. Avvenuta a San Clou vicino a Parigi. Stampata in Lione per Giovan Pilleotta, \& ristampata in Turino per Michele Cavaleris, \& in Rauenna per Francesco Tebaldini, \& di novo in Ferrara (Ferrara, 1589), ustc 806511.

57 On the career of Pillehotte see, Henri Baudier, Bibliographie Lyonnaise. Recherches sur les imprimeurs, libraires, relieurs et fondeurs des lettres, Tome II (Lyon, 1893-6), pp. 224-6.

58 Jacqueline Boucher, Présence Italienne à Lyon à la Renaissance: du milieu du XVème à la fin du XVIème Siècle (Lyon: Editions LUGD, 1994).

59 For the importance of Lyon in publishing of books see Angela Nuovo, The Book Trade in the Italian Renaissance (Leiden: Brill, 2013), pp. 265-82.

6o On printing by the Catholic league see, Denis Pallier, Recherches sur l'imprimerie à Paris pendant la Ligue: 1585-1594 (Paris: Champion, 1975), and Alexander S. Wilkinson, Mary 
A large number of pamphlets on the appearances of comets and other miraculous signs in the sky were published in France by League presses. These type of news pamphlets had moral purposes as they illustrated the might of God and the truth of the Catholic Church. In 1591 a pamphlet on the appearance of miraculous crucifixes in Paris and Bourges was printed in Milan, Pavia and Ferrara. ${ }^{61}$ The pamphlet was an Italian translation of a French edition published by Jean Pilehotte in Lyon. A few years earlier, in 1588 a pamphlet on the appearance of a comet in the town of Rupelmonde in the Low Countries was published in Venice. ${ }^{62}$ This was not a translation but a report based on a letter sent by Giovanni Euschelf. According to the unknown author, all the heretics were so afraid that afterwards they converted and 'returned to the flock of the sacred church'. ${ }^{63}$ During those years, there was an important difference between news on the French wars of religion and news on the Dutch Revolt: while news from the Low Countries was still based upon letters and manuscript reports, news from France was now mostly based upon printed French news pamphlets.

\section{Catholic News Networks}

Between 1587 and 1593, reports of the victories of the Catholic League over the Protestant contender to the French crown, Henri of Navarre, were translated into Italian and published in Italian cities, even if the victories were in fact only relatively minor skirmishes. ${ }^{64}$ During the campaign against the German

Queen of Scots and French Public Opinion, 1542-160o (Basingstoke: Palgrave Macmillan, 2004), pp. 103-26.

61 Discorso delle croci miracolosamente apparse nella citta di Parigi, Burges Corbia Amiens e Montdidier come leggendo intenderete. Stampate in Lione, in Milano, in Pavia, \& ristampata in Ferrara (Ferrara, 1591), Ustc 806652.

62 Giovanni Euschelf, Relatione del gran prodigio apparso nouamente sopra la città di Rupelmonde in Fiandra. Dove s'intende quanto tempo sia durato, il terrore che ha posto a que' popoli, \& la conuersion di molti heretici (Venice, 1588), ustc 828505 .

63 Euschelf, Relatione del gran prodigio, p. 4: "si sono ridotti nel gregge di Santa Chiesa".

64 Il Rincontro fatto delle genti dell'esercito de'principi catholici, et di quelle del Principe di Bear, detto Rè di Navarra. Con l'aviso della ferita sua, \& della presa di Nouocastello (Turin, 1592), USTC 806763 is a translation of Discours du rencontre suivy entre l'armee des princes catholiques et celle du Bearnois (Lyon, 1592), USTC 11192 and Presa della città di Carcassona, occupata da heretici, et ribelli, fatta per il signor duca di Gioiosa governatore, \& luogotenente generale per la corona di Francia nella provincia di Linguadoca (n.p., 1592), USTC 806763 is a translation of Discours veritable de la prinse de la ville basse de Carcassonne (Lyon, 1592), USTC 11178. 
reistres in France in 1587 the League fully exploited the potential of printed news pamphlets. ${ }^{65}$ Many of these news pamphlets, celebrating Henri duc de Guise as a Catholic hero, were translated into Italian. ${ }^{66}$ The news on his victory at Vimory in 1587 , for example, was translated 'into Tuscan' from the French edition by Pilehotte and printed in Lucca. ${ }^{67}$ The anonymous translator added more background information on some military commanders, so that his Lucchese readers could have a better understanding of the events. At the end of the pamphlet, he explained he had translated it so those who had no knowledge of French could enjoy reading of this successful battle. 68 This example indicates that local audiences, in this case in the small Republic of Lucca, were interested in hearing and reading news on foreign events.

During the 1590 s the same news was printed in several Catholic cities. The news of the successful relief of the siege of Paris in 1590 by Farnese was printed in Paris and also in Lyon by Pillehotte, subsequently in Brussels by the official printer Rutger Velpius, and in Cologne by Lambert, as well as in various Italian cities. ${ }^{69}$ The dissemination of this news pamphlet suggests the existence of Catholic news networks. These Catholic news networks connected several cities including Brussels, Cologne, Paris, Lyon and Rome. In those Catholic cities, printers published the same news accounts in their own vernacular. In the

65 See Pallier, Recherches imprimerie à Paris pendant la ligue, p. 65.

66 Auuisi di piu cose successe in Francia dal mese di agosto in qua. Con la presa di san Massento dal duca di Gioiosa, et noua delle cornette di reistri tagliati à pezzi dal duca di Ghisa (Rome, 1587), ustC 806170 is an adapted translation of La prinse de la ville de Sainct Maixant par monseigneur le duc de Joyeuse (Lyon, 1587), ustc 11841.

67 Largo discorso della rotta di ventuno stendardo, o cornette di ristri. Data a Vimori in Gattinese presso Montargis alliXXVI di ottobre MDLXXXVII. Dalli signori duchi di Guisa \& di Meina. Tradotto di lingua francese in toscano (Lucca, 1587) UsTC 806228. It was a translation of Ample discours de la deffaite de vingtune Cornettes de Reystres: faicte à Vimory en Gastinois pres Montargis. Par messeigneurs les Ducs de Guyse et du Mayne (Lyon, 1587), USTC 11870 .

68 Largo discorso della rotta di ventuno stendardo, sig. A7.

69 For the Italian pamphlets see n. 2, Pedro Cornejo, Bref discours et veritable des choses plus notables arrivees au siege memorable de la renommee ville de Paris et defence d'icelle par le duc de Nemours, contre le roy de Navarre (Paris, 1590), usTC 8490 and subsequent editions: Pedro Cornejo, Bref discours et veritable des choses plus notables arrivees au siege memorable de la renommee ville de Paris et defence d'icelle par le duc de Nemours, contre le roy de Navarre (Lyon, 1590), UstC 8491 and Pedro Cornejo, Bref discours et veritable des choses plus notables arrivees au siege memorable de la renommee ville de Paris et defence d'icelle par le duc de Nemours, contre le roy de Navarre (Brussels, 1590), USTC 13620; Warhafftiger und eigentlicher bericht auß Franckreich was sich zwischen dem König von Navarra und der herrlichen weitberhümpten statt Pariß zugetragen wie er den achten kay darfur gezogen sie hart belegert mitxl. tausent mann sampt wie der Printz von Parma (Cologne, 1590), USTC 705907. 
circulation and transmission of news, translation thus played an important role. These publishers presented their separate audiences with the same narrative and moral frameworks.

The news of the escape of Charles de Lorraine, Duke of Guise, from Tours in 1591, where he had been jailed in 1588 after the murder of his father Henri and Cardinal of Guise, serves as a case in point. This news was published in several cities in France, such as Lyon again by Pillehotte and in cities in the Low Countries such as Arras by De la Rivière and Brussels by Velpius. ${ }^{70}$ The news was also published in Rome by the Blado firm in an adapted translation of the French original. ${ }^{71}$ Charles de Lorraine's escape was attributed to divine intervention. According to the news pamphlet, every good Catholic had to pray to God that this liberation would result in the progress of the Catholic religion and the ruin of the heretics in France. Publishers were crucial in the creation of Catholic news networks and in reaching a wide Catholic audience. In several cities outside France, a Catholic audience was thus encouraged to engage fully in the struggle against heretics. News was mobile and crossed a north-south divide in Europe's news networks. Its mobility was not limited by geographical boundaries but predominantly by confessional ones. This would soon change, and the political realities would create new networks for their distribution. The conversion of Henri IV to Catholicism in 1593 and the subsequent war with the Spanish-Habsburg monarchy are examples of such a change.

Italian printers published the Habsburg victories, but they did not publish Henri IV's victories over the Habsburg army. The Italian news production was strongly influenced by the presence of Habsburg power on the Italian peninsula. News of the victories of the Habsburg army against the French king Henri IV, such as the siege of Calais in 1596 and the siege of Amiens in 1597, were highly publicised in the Netherlands. ${ }^{72}$ The Milanese edition of the

$70 \quad$ Discours veritable de la delivrance miraculeuse de monseigneur le duc de Guyse nagueres captif au chasteau de Tours (Lyon, 1591), USTC 29308 and Discours veritable de la delivrance miraculeuse de monseigneur le duc de Guyse nagueres captif au chasteau de Tours (Brussels, 1591), USTC 13621.

71 Relatione vera della prigionia, \& liberatione del Duca di Guysa, dal castello, \& città di torsi, alli xv d'agosto passato, giorno della festa dell'assontione della gloriosissima Vergine (Rome, 1591), UstC 806693 and Relatione vera della prigionia, \& liberatione del Duca di Guysa, dal castello, \& città di torsi, allixv d'agosto passato (Florence, 1591), usTC 806692 and Relatione vera della prigionia, \& liberatione del Duca di Guysa, dal castello, \& città di torsi, alli xv d'agosto passato, giorno della festa dell'assontione della gloriosissima Vergine (Perugia, 1591), USTC 806707 .

72 Paul Arblaster, From Ghent to Aix: How They Brought the News in the Habsburg Netherlands (1550-1700) (Leiden: Brill, 2014), pp. 52-68. 
account of the siege of Amiens, was based upon the original French edition published in Arras by De la Rivière. ${ }^{73}$ Several of these news pamphlets, first published in Arras by Guillaume de la Rivière, were probably written by Leaguers who were in exile in the Habsburg Netherlands. ${ }^{74}$ The strong Catholic language was still present. Many exiled Leaguers still considered Henri IV as a Protestant and presented the battles as an ongoing struggle against heresy. In their eyes, the Habsburg monarchy was the only true representative and defender of the Catholic faith. At the end of the sixteenth century, the Catholic news network had become a Habsburg network. Many of these victories, were now also published in Spanish cities such as Barcelona, Seville and Granada. ${ }^{75}$ News circulated from the Habsburg Netherlands, to Italian cities and Habsburg Spain. This Habsburg network of news celebrated these battles as triumphs of Catholicism and as deliverance from heretics.

\section{Conclusion}

The cities of the Italian peninsula sustained a lively market for printed news reports on foreign conflicts. The Italian case offers important clues to the function of printed news. Printed news reports clearly aroused support for the Catholic cause. Publishers singled out specific events from the stream of information present in handwritten avvisi. They presented to a broad and local audience those events which they regarded as crucial. In some cases, news was printed because it offered the opportunity to craft a clear sense of identity.

73 Breve et vero discorso delli particolari successi occorsi sotto la città d'Amiens, tra gli assediati, \& gli inimici. Dopoi il martedi 15. mercoledi 16 \& la giobba 17. di luglio fino il lunedi seguente alli 21 (Milan, 1597), USTC 807118. The title page stated it was printed 'conforme la copia stampata in Aras', see Discours touchant la prise admirable de la grande et puissante ville d'Amiens (Arras, 1597), ustc 13462.

74 Robert Descimon and José Javier Ruiz Ibáñez, Les Ligueurs de L'exil: Le refuge Catholique Français après 1594 (Seyssel: Champ-Vallon, 2005), pp. 139-41.

75 Relacion de una felicissima vitoria que ha tenido contra los franceses en Dorlan en Picardia don Pedro Henriquez Conde de Fuentes (Barcelona, 1595), ustc 352745; Relacion muy cierta y verdadera, que trata de la iornada que el Serenissimo Principe Cardenal Don Alberto de Austria, que por mandado de su Magestad, fue a entender en las cosas de los estados de Flandes, sobre la toma y sucesso de Cales (Seville, 1596), ustc 338857; Relacion nueva y muy verdadera de los sucessos del Archiduque Cardenal Alberto de Austria, en los estados de flandes, en este año de 1596 (Seville, 1596), usTC 338860; La admirable toma de la ciudad de Amiens, en 11 de março de 1597 años (Granada, 1597), USTC 338095 and La admirable toma de la ciudad de Amiens, en 11 de março de 1597 años (Seville, 1597), USTC 338094 . 
Sometimes this was a local identity, as was the case with the Tuscan soldiers in 1569, but very often it was about the Italian nation. In those pamphlets, the Italian identity was above all defined by the idea that Italians were valorous and brave Catholic fighters. The news pamphlets provided a narrative for these events and a context in which those events could be interpreted. It must be said, however, that only good news was printed. Both military reports and polemical news celebrated Catholic triumphs. In the case of the Low Countries, the reports were written mostly by high-ranking soldiers and there is a very close association between manuscript and print. In the case of France, with the rise of the League, many reports were translations of French editions published in Lyon. This difference in Italian production may be explained by the established connections between France and Italy and by the close ties Italian printers had with printers in Lyon.

At the end of the sixteenth century, in several Catholic cities, publishers started to publish simultaneously the same news report, which points to the existence of Catholic news networks. The news on the cruel death of Balthasar Gérard, the killing of Henri III, the news on the siege of Paris in 1590, and the news of Guise's escape in 1591 are all examples of news events where the same reports were printed in several Catholic cities each time by the same publishers. In those cities the same news was printed and presented to inform, but most of all to convince Catholic audiences of their common goal of fighting heretics. In this sense a transnational Catholic news network existed which included the Habsburg lands, part of the Holy Roman Empire, France and Italy. At the same time, such networks could change rapidly. All of this serves to demonstrate that we need to study the movement of news in Europe and the significance of translation more closely. 